\begin{tabular}{|l|l|l|}
\hline Received : April 2020 & Accepted: May 2020 & Published : July 2020 \\
\hline
\end{tabular}

\title{
Faktor-Faktor yang Mempengaruhi Kualitas Penyajian Laporan Keuangan di Lingkungan Pemerintah Kota Padang Panjang
}

\author{
Popi Fauziati $^{1^{*}}$, Novaria Rahmah, Mukhlizul Hamdi ${ }^{2}$ \\ 1,2 Jurusan Akuntansi, Fakultas Ekonomi dan Bisnis, Universitas Bung Hatta \\ *email :popifauziati@bunghatta.ac.id
}

\begin{abstract}
This study is intended for examining the impact of imposition of Government Accounting Standards and Human Resource Competencies to the quality of the presentation of the Regional Financial Statements within the Government of Padang Panjang City, West Sumatera, Indonesia. The phenomenon underlining this study is prompted by the audit results by the Audit Board of the Republic of Indonesia (BPK-RI) in 2016 when there were 14 findings of nonconformity consisting of 8 findings on Compliance and 6 findings on Internal Control Systems, and those in 2017 when there were 11 findings consisting of 5 findings on Compliance and 6 findings on Internal Control Systems. In addition, with regard to Human Resources Competence, there are still employees who are not / less competent, especially in the financial section in government organization. The sampling technique was purposive sampling, with 100 respondents, in which case only 50 respondents returned the questionnaires. Hypothesis testing was performed by using Multiple Linear Regression Analysis and SPSS-16 application tool. Results of the study showed that: (1) Application of Government Accounting Standards gave positive impact on the Quality of the Presentation of Government Financial Statements, (2) Imposition of Human Resources Competence significantly improved the Quality of the Presentation of Government Financial Statements.
\end{abstract}

Keywords : government accounting standards, human resources competence, quality of financial statement

\begin{abstract}
Abstrak
Penelitian ini bertujuan untuk menguji pengaruh penerapan standar akuntansi pemerintah dan kompetensi sumberdaya manusia terhadap kualitas penyajian Laporan Keuangan Daerah di lingkungan Pemerintah Kota Padang Panjang. Fenomena penelitian ini didasarkan pada hasil pemeriksaan BPK-RI pada Tahun 2016 terdapat sejumlah 14 (empat belas) temuan yang terdiri dari 8 (delapan) temuan tentang kepatuhan dan 6 (enam) temuan tentang sistem pengendalian internal. Pada tahun 2017 terdapat sejumlah 11 (sebelas) temuan yang terdiri dari 5 (lima) temuan tentang kepatuhan dan 6 (enam) temuan tentang sistem pengendalian internal. Begitu juga dengan kompetensi Sumber Daya Manusia, masih ada karyawan yang tidak / kurang kompeten, terutama di bagian keuangan di organisasi pemerintah.Teknik pengambilan sampel adalah purposive sampling, dengan 100 responden, tetapi hanya 50 responden mengembalikan kuesioner.Pengujian hipotesis menggunakan analisis regresi linier berganda dengan menggunakan aplikasi SPSS 16.Hasil penelitian menunjukkan bahwa (1) penerapan standar akuntansi pemerintah memiliki pengaruh positif terhadap kualitas penyajian laporan keuangan pemerintah, (2) kompetensi sumberdaya manusia berpengaruh positif terhadap kualitas penyajian laporan keuangan pemerintah.
\end{abstract}

Kata kunci : standar akuntansi pemerintah, kompetensi sumberdaya manusia, kualitas penyajian laporan keuangan

\section{Pendahuluan}

Pemerintah Indonesia terus melakukan upaya-upaya untuk meningkatkan kualitas terhadap transparansi dan akuntabilitas pengelolaan keuangan negara. Hal ini ditujukan agar tercipta tata kelola pemenrintah yang baik. Salah satu cara untuk meningkatkan transparansi dan akuntabilitas adalah dengan membuat sebuah standar pelaksanaan pengelolaan keuangan tersebut. Standar ini akan digunakan oleh berbagai pihak yang berkepentingan seperti pihak pelaksana pengelolaan laporan keuangan, pemeriksa laporan keuangan dan pihak yang membaca laporan keuangan. Di bidang pemerintahan telah dibuat Standar Akuntansi Pemerintah (SAP) yang dijadikan sebagai pedoman dalam menyusun dan menyajikan laporan keuangan pemerintah di tingkat pusat dan di daerah Selain menjadi acuan dalam 
penyusunan dan penyajian laporan keuangan, Standar Akuntansi Pemerintah memiliki kekuatan hukum sebagai pedoman untuk meningkatkan kualitas laporan keuangan pemerintahan di Indonesia. Pemerintah menunjukkan Komite Standar AkuntansiPemerintah sebagai lembaga yang mengesahkan Standar Akuntansi Pemerintah(Haq, 2014).

Pembuatan laporan keuangan Pemda merupakan jawaban dari tuntutan terhadap pengelolaan keuangan daerah yang tertib, jelas, dan akuntabel agar terwujudnya pemerintah yang bersih dan transparan. Laporan keuangan tersebut setidak-tidaknya berupa Laporan Realisasi Anggaran, Neraca, Laporan Arus Kas dan Catatan atas Laporan Keuangan.Laporan Keuangan diharapkan memiliki kualitas dan mampu memberi manfaat dalam upaya pengambilan kebijaksanaan suatu pemerintahan di masa yang akan datang. Laporan keuangan yang berkualitas dapat dilihat melalui opini dari BPK-RI. Opini dari BPK-RI memiliki strata/tingkatan tertinggi adalah Wajar Tanpa Pengecualian (WTP) kemudian tingkatan berikutnya adalah Wajar Dengan Pengecualian (WDP), Tidak Wajar (TW), dan Tidak Menyatakan Pendapat (TMP).

Pada kenyataannya masih ada laporan keuangan yang belum sesuai dengan standar akuntasi pemerintahan yang berlaku.Hal inidibuktikan dengan temuan-temuan auditor, baik auditor internal seperti Inspektorat Kota/Kabupaten maupun auditor eksternal seperti Badan Pemeriksa Keuangan Republik Indonesia (BPK-RI). Berdasarkan data di lingkungan pemerintah Kota Padang Panjang ditemukan hasil pemeriksaan BPK-RI pada Tahun 2016 terdapat sejumlah 14 (empat belas) temuan yang terdiri dari 8 (delapan) temuan tentang Kepatuhan dan 6 (enam) temuan tentang sistem pengendalian internal. Pada tahun 2017 terdapat sejumlah 11 (sebelas) temuan yang terdiri dari 5 (lima) temuan tentang Kepatuhan dan 6 (enam) temuan tentang Sistem Pengendalian Internal.Walaupun dalam 2 (dua) tahun terakhir Pemerintah Kota Padang Panjang sudah mendapatkan opini WTP dari BPK-RI, namun laporan keuangan pemerintah Kota Padang Panjang masih terdapat catatan dari BPKRI, salah satucatatannya adalah masih belum tepatnya pencatatan aset-aset daerah di Lingkungan Pemerintah Kota Padang Panjang. Banyaknya aset milik Pemerintah Kota Padang Panjang yang belum memiliki kejelasan status seperti barang-barang hibah yang diterima dari Pemerintah Pusat(BPKD Kota Padang Panjang, Tahun 2019).

Kompetensi sumberdaya manusia (SDM) sangat penting dalam hal pengelolaan dan penyajian informasi keuangan sehingga laporan keuangan menjadi tepat waktu dan akurat. Hasil observasi awal di pemerintahan Kota Padang Panjang ditemukan sebanyak 23\% pembuat laporan keuangan masih ada yang tidak memiliki kompetensi yang memadai. Sumber daya manusia yang tidak/kurang berkompeten khususunya pada bidang/bagian keuangan pada tiap-tiap OPD.Hal ini terlihat dari latar belakang pendidikan tidak sesuai dengan pekerjaannya.Berdasarkan latar belakang, maka rumusan masalah dalam penelitian ini yaitu sebagai berikut:Apakah penerapan standar akuntansi pemerintahan dan kompetensi sumberdaya manusia berpengaruh terhadap kualitas penyajian Laporan Keuangan Daerah di lingkungan Pemerintah Kota Padang Panjang?

\subsection{Pengaruh Penerapan Standar Akuntansi Pemerintah terhadap Kualitas Penyajian Laporan Keuangan Pemerintah Daerah}

Standar Akuntansi Pemerintah (SAP) mengatur tentang penyajian laporan keuangan yang dilakukan oleh Pemerintah Daerah atau Pemerintah Pusat. Kegunaan dari adanya standar adalah meningkatkan kualitas laporan keuangan terutama dari sisi konsistensi, daya banding, keterpahaman, relevansi dan keterandalan laporan keuangan (Mahmudi, 2016).Hasil penelitian Pujanira dan Taman (2017) menunjukkan bahwa penerapan Standar Akuntansi Pemerintah berpengaruh positif terhadap kualitas Laporan Keuangan Pemerintah Daerah.Hal ini sejalan dengan hasil penelitian Abidin, dkk (2018) yang menunjukkan bahwa variabel penerapan SAP berpengaruh signifikan terhadap kualitas laporan keuangan pemerintah daerah Kota Malang.Sako dan Lantowa (2018) menemukan penerapan SAP berpengaruh positif 
terhadap kualitas penyajian laporan keuangan pada DPPKAD Kabupaten Gorontalo.Berdasarkan penjelasan diatas, maka hipotesis dalam penelitian ini adalah :

H1: Penerapan Standar Akuntansi Pemerintahan berpengaruh terhadap kualitas penyajian laporan keuangan daerah di Lingkungan Pemerintah Kota Padang Panjang

\subsection{Pengaruh Kompetensi Sumber Daya Manusia terhadap Kualitas Penyajian Laporan Keuangan Pemerintah Daerah}

Human capital perusahaan adalah sumberdaya manusia yang bekerja di perusahaan dan terdiri dari kumpulan pengetahuan, keterampilan, dan kemampuan karyawan untuk memberikan layanan profesional dan economic rent. Human capital juga berupa gagasan dan inovasi dimana karyawan yang memiliki human capital yang tinggi akan memberikan pelayanan yang konsisten dan berkompetensi tinggi (Sutaryo, 2011).Hubungan kompetensi sumber daya manusia dengan kualitas laporan keuangan pemerintah daerah, menurut Wahyono (2014) menyatakan bahwa: "Dalam menghasilkan suatu nilai informasi yang bernilai (keterandalan) melibatkan dua elemen pokok yaitu: informasi yang dihasilkan dan sumber daya menghasilkannya".informasi lapora Berkaitan dengan sumberdaya yang menghasilkan laporan keuangan, semakin kompeten sumberdaya yang mengerjakan atau membuat laporan keuangan maka laporan keuangan yang dihasilkan mempunyai kemampuan dalam informasi yang semakin benar atau valid. Hasil penelitian Pujanira dan Taman (2017), dan Abidin dkk (2018) menunjukkan bahwa kompetensi SDM berpengaruh positif terhadap kualitas laporan keuangan Pemerintah Daerah. Temuan ini juga sejalan dengan hasilpenelitian Mahardini dan Miranti (2018), yang menunjukkan bahwa Kompetensi SDM berpengaruh positif terhadap kualitas laporan keuangan Pemerintah Provinsi Banten.

Berdasarkan penjelasan diatas, maka hipotesis dalam penelitian ini adalah:

H2: Kompetensi sumber daya manusia berpengaruh terhadap kualitas penyajian laporan keuangan pemerintah daerah di Lingkungan Pemerintah Kota Padang Panjang

\section{Metodologi}

Populasi penelitian ini adalah pegawai negeri sipil yang bekerja di seluruh Organisasi Perangkat Daerah (OPD) di Lingkungan Pemerintah Kota Padang Panjang. OPD adalah sebagai entitas yang melakukan pelaporan keuangan dalam penyelenggaraan pemerintah daerah dan di lingkungan Pemerintah Kota Padang Panjang berjumlah sebanyak 24 (dua puluh empat) OPD. Teknik pengambilan sampel dalam penelitian ini adalah menggunakan Teknik Purposive Sample, yaitu teknik penentuan sampel yang dilakukan secara sengaja menunjuk orang-orang yang dianggap mampu memberikan kebutuhan data yang diperlukan (Sekaran, 2014). Sampel dalam penelitian adalah Kepala Sub Bagian keuangan, Kepala Sub Bagian evaluasi dan pelaporan, Bendahara Pengeluaran/pemegang Kas OPD, Verifikator keuangan dan Staf pada subbagian keuangan.Media untuk mengumpulkan data digunakan kuesioner atau angket.

\subsection{Defenisi Operasional dan Pengukuran Variabel}

Kuesioner yang digunakan dalam penelitian ini didasarkan pada kuesioner Sudiarianti (2015) dan Pujanira dan Taman (2017). Kualitas Penyajian Laporan Keuangan Daerah diukur dengan 6 (enam) butir pertanyaan yakni :

1. Apakah Instansi/lembaga tempat anda bekerja menyelesaikan laporan keuangan tepat waktu dan lengkap?

2. Apakah transaksi yang disajikan oleh instansi/lembaga tempat anda bekerja tergambar dengan jujur dalam laporan keuangan dan bebas dari kesalahan yang bersifat material?

3. Apakah ditempat anda bekerja, informasi keuangan yang dihasilkan dapat diuji? 
4. Apakah instansi/lembaga tempat anda bekerja menyajikan informasi yang diarahkan untuk kebutuhan umum dan tidak berpihak pada kebutuhan khusus?

5. Apakah informasi keuangan yang disajikan oleh instansi/lembaga tempat anda bekerja dapat dibandingkan dengan laporan keuangan periode sebelumnya?

6. Apakah informasi keuangan yang disajikan oleh instansi/lembaga tempat saya bekerja dapat dipahami oleh pengguna?

Penerapan Standar Akuntansi Pemerintahan diukur dengan6 (enam) butir pertanyaan yakni :

1. Apakah laporan keuangan OPD menyajikan Laporan Realisasi Anggaran berdasarkan basis kas serta menyajikan realisasi pendapatan dan belanja yang diakui pada saat kas masuk atau kas keluar?

2. Apakah Laporan arus kas menyajikan informasi mengenai keluar masuk kas selama periode akuntansi yang diklasifikasikan berdasarkan aktivitas operasi, investasi, pendanaan dan transitoris. Serta catatan atas laporan keuangan OPD disusun secara sistematis dan mengungkapkan penjelasan pos-pos laporan keuangan?

3. Apakah pada akhir periode akuntansi, catatan persediaan disesuaikan dengan hasil inventarisasi fisik, dimana Investasi OPD diklasifikasikan menjadi dua yaitu investasi jangka pendek dan investasi jangka panjang?

4. Apakah aset tetap yang diklasifikasikan berdasarkan kesamaan sifat atau fungsinya dalam aktivitas operasi entitas serta Konstruksi dalam pengerjaan adalah aset yang digunakan untuk operasional OPD dan dimanfaatkan dalam jangka panjang?

5. Apakah kewajiban OPD diklasifikasikan menjadi dua yaitu kewajiban jangka pendek dan kewajiban jangka panjang dan dicatat sebesar nilai nominal dimana jumlah koreksi periode sebelumnya dilaporkan dengan menyesuaikan saldo anggaran Lebih maupun saldo ekuitas serta Koreksi yang berpengaruh material pada periode berikutnya?

6. Apakah laporan keuangan konsolidasian OPD berisi jumlah komparatif dengan periode sebelumnya dan laporan operasional OPD disajikan minimal sekali dalam setahun?

Kompetensi Sumber Daya Manusia diukur dengan 6 (enam) butir pertanyaan yakni :

1. Apakah anda telah mengerti peran dan fungsi yang jelas dalam pengelolaan keuangan dan bekerja berdasarkan pedoman mengenai proses akuntansi yang telah ada?

2. Apakah anda telah menjalankan tugas sesuai dengan fungsi akuntansi yang sesungguhnya?

3. Apakah anda telah mendapatkan pelatihan untuk dapat menunjang kemampuan bekerja di bidang akuntansi?

4. Apakah anda memahami materi pelatihan yang diberikan dimana materi pelatihan yang saya ikuti diberikan sesuai dengan kebutuhan sebagai fungsi pengelola keuangan?

5. Apakah anda memiliki pengalaman untuk menjalankan tugas di bidang akuntansi?

6. Apakah anda memiliki pengalaman di bidang akuntansi, sehingga dapat membantu saya mengurangi kesalahan dalam bekerja?

\subsection{Metode Analisa Data}

Sebelum dilakukan pengujian hipotesis, data yang diperoleh harus diuji kualitas data dengan pengujian reliabilitas dan validitas. Selanjutnya data akan diuji dengan Uji Normalitas, Multikolinearitas dan Heteroskedastisitas. Untuk pengujian hipotesis dilakukan dengan menggunakan regresi berganda. 


\section{Hasil dan Pembahasan}

\subsection{Hasil Uji Reliabilitas dan Validitas}

Berdasarkan tabel 1 dapat disimpulkan bahwa masing-masing variabel penerapan standar akuntansi pemerintah memiliki cronbach alpha di atas 0,60, nilai KMO sebesar 0,50 sehingga dapat disimpulkan data reliabel dan valid.

\section{Tabel 1.Hasil Reabilitas dani Validitas}

\begin{tabular}{lccc}
\hline \multicolumn{1}{c}{ Variabel } & Cronbach Alpha & KMO & Keterangan \\
\hline Penerapan SAP $\left(\mathrm{X}_{1}\right)$ & 0,802 & 0,707 & Reliabel dan Valid \\
$\begin{array}{l}\text { Kompetensi SDM } \\
\left(\mathrm{X}_{2}\right)\end{array}$ & 0,882 & 0,786 & Reliabel dan Valid \\
$\begin{array}{l}\text { Kualitas Penyajian } \\
\text { Lap. Keu (Y) }\end{array}$ & 0,648 & 0,542 & Reliabel dan Valid \\
\hline
\end{tabular}

Sumber : Hasil Pengolahan Data

\subsection{Deskripsi Data}

Deskripsi hasil data survey untuk masing-masing variabel dapat dilihat pada tabel di bawah ini:

Tabel 2.Deskripsi Data

\begin{tabular}{lccc}
\hline \multicolumn{1}{c}{ Uraian } & $\begin{array}{c}\text { Penerapn SAP } \\
\left(\mathbf{X}_{\mathbf{1}}\right)\end{array}$ & $\begin{array}{c}\text { Kompetensi SDM } \\
\left(\mathbf{X}_{\mathbf{2}}\right)\end{array}$ & $\begin{array}{c}\text { Kualitas Penyajian Lap. Keu } \\
(\mathbf{Y})\end{array}$ \\
\hline Mean & 18,84 & 21,10 & 19,88 \\
Median & 19,00 & 21,00 & 20,00 \\
Standar & 3,443 & 3,976 & 2,624 \\
Deviation & & & \\
Minimum & 12 & 13 & 13 \\
Maximum & 28 & 30 & 28 \\
Count & 50 & 50 & 50 \\
\hline \multicolumn{2}{c}{ Sumber : Hasil Pengolahan Data }
\end{tabular}

\subsection{Uji Asumsi Klasik}

Untuk hasil pengujian asumsi klasik, hasil uji normalitas diuji dengan Kolmogorov Smirnov dan nilai Asymp. Sig > 0,05 sehingga ketiga varibel dapat dinyatakan berdistribusi normal. Untuk hasil pengujian multikolinieritas, nilai tolerance dan VIF berada disekitar 1 dan dibawah 10 sehingga data tidak mengalami gejala multikolinearitas..Uji heteroskodesitas yangdilakukan uji Glejser menunjukkan nilai sig> 0,05, maka tidak terdapat gejala heterikedastisitas ( Ghozali, 2016).

\subsection{Analisis Hasil dan Pembahasan}

Modelanalisis regresi linear akan menguji Penerapan Standar Akuntansi Pemerintahan (SAP), Kompetensi Sumber Daya Manusia (SDM) terhadap kualitas penyajian laporan keuangan (KPLK). Hasil analisis data dapat dilihat pada tabel berikut. 
Tabel 3. Hasil Analisis Regresi Linear Berganda

\begin{tabular}{llcrccc}
\hline No & Keterangan & $\begin{array}{c}\text { Koefisien } \\
\text { Regresi }\end{array}$ & t hitung & Sig. & $\begin{array}{c}\text { Batas } \\
\text { sig }\end{array}$ & Ket \\
\hline 1. & Konstanta & 4,463 & & & 0,05 & Ha diterima \\
2. $\quad$ Penerapan SAP & 0,484 & 7,841 & 0,000 & 0,05 & Ha diterima \\
3. Kompetensi SDM & 0,299 & 5,596 & 0,000 & 0,05 & \\
\hline R square $=0,700$ & & & & & \\
F hitung $=54,865$ & & & & & \\
F Sig. $=0,000$ & & & & &
\end{tabular}

Sumber :Hasil Pengolahan Data SPSS V.16. 2020.

Berdasarkan hasil analisis data maka nilai koefisien regresi masing-masing variabel penelitian dapat disubtitusikan ke dalam persamaan regresi linear berganda sebagaiberikut.

\section{Kualitas Penyajian Laporan Keuangan = 4,463 + 0,484PSAP + 0,299 KSDM}

Berdasarkan tabel 3, nilai R-square sebesar 0,700 menunjukkan besarnya Penerapan Standar Akuntansi Pemerintahan, Kompetensi Sumber Daya Manusia terhadap Kualitas Penyajian Laporan Keuangan adalah sebesar 70\% dan sisanya sebesar 30\% dipengaruhi oleh variabel lain yang termasuk ke dalam model penelitian.

Berdasarkan analisis data pada tabel 3 diketahui bahwa nilai $\mathrm{F}$ hitung adalah sebesar 54,865 dengan nilai signifikansi 0,000 . Jika nilai signifikansi dibanding dengan alpha $(0,000$ $<0,05)$. Hal ini berarti model regresi yang dihasilkan adalah prediktor valid dalam mengestimasi variabel terikat.Koefisien korelasi parsial adalah suatu nilai yang menggambarkan hubungan parsial antara satu variabel dengan varibel lainnya dengan menganggap variabel lain di luar kedua variabel tersebut tetap/konstan. Output SPSS dalam penelitian ini menjelaskan hasil pengujian hipotesis sebagai berikut :

Hipotesis pertama $\left(\mathrm{H}_{1}\right)$ pada penelitian adalah Penerapan Standar Akuntansi Pemerintahan (SAP) berpengaruh positif terhadap Kualitas Penyajian Laporan Keuangan.Berdasarkan analisis regresi sebagaimana terlihat pada tabel 3 diketahui nilai koefisien regresi variabel Penerapan Standar Akuntansi Pemerintahan (PSAP) sebesar 0,484 dengan nilai signifikansi sebesar 0,000 . Jika nilai signifikansi dibandingkan dengan tingkat signifikansi yang digunakan $(\alpha=0,05)$ maka terbukti bahwa nilai signifikansi lebih kecil dari tingkat signifikansi yang digunakan $(0,000<0,05)$. Hal ini berarti hipotesis pertama diterima pada tingkat kepercayaan 95\% artinya Penerapan Standar Akuntansi Pemerintahan (SAP) berpengaruh positif terhadap Kualitas Penyajian Laporan Keuangan Pemerintahan. Hasil penelitian ini sesuai dengan hasil penelitianNordiawan dan Hertianti (2010), Pujanira dan Taman (2017),Abidin dkk (2018), Mahardini dan Miranti (2018) dan Sako dan Lantowa (2018).

Hipotesis kedua $\left(\mathrm{H}_{2}\right)$ pada penelitian ini adalah kompetensi sumberdaya manusia berpengaruh positif terhadap kualitas penyajian laporan keuangan. Berdasarkan analisis regresi sebagaimana terlihat pada tabel 3 diketahui nilai koefisien regresi variabel kompetensi sumber daya manusia sebesar 0,299 dengan nilai signifikansi sebesar 0,000. Jika nilai signifikansi dibanding dengan tingkat signifikansi yang digunakan $(\alpha=0,05)$ maka terbukti bahwa nilai signifikansi lebih kecil dari tingkat signifikansi yang di gunakan $(0,000<0,05)$. Hal ini berarti hipotesis kedua diterima pada tingkat kepercayaan 95\%, artinya kompetensi 
sumber daya manusia berpengaruh positif terhadap kualitas penyajian laporan keuangan pemerintahan.Hasil penelitian ini konsisten dengan hasil penelitian Wahyono (2014), Pujanira dan Taman (2017), Abidin dkk (2018), Mahardini dan Miranti (2018).

\section{Kesimpulan}

Berdasarkan hasil penelitian maka dapat disimpulkan bahwapenerapan standar akuntansi pemerintah (SAP) dan kompetensi sumberdaya manusia berpengaruh terhadap kualitas penyajian laporan keuangan (KPLK) di Kota Padang Panjang sebesar 70 persen sedangkan sisa sebesar 30 persen dipengaruhi oleh variabel lain.Berdasarkan hasil uji F (Uji Simultan), penerapan standar akuntansi pemerintah (SAP) dan kompetensi sumberdaya manusia secara simultan mempengaruhi kualitas penyajian laporan keuangan (KPLK) di Kota Padang Panjang.Untuk hasil uji t (uji parsial), penerapan standar akuntansi pemerintah (SAP) dan kompetensi sumberdaya manusia secara parsial berpengaruh signifikan kualitas penyajian laporan keuangan di Kota Padang Panjang.

\section{Saran}

Berdasarkan hasil penelitian dan pengalaman lapangan maka peneliti menyarankan kepada pemerintah selaku pembuat laporan keuangan untuk memperhatikan variabel-variabel lain yang mempengaruhi kualitas laporan keuangan seperti penggunaan teknologi, sistem administrasi, regulasi dan politik agar kualitas laporan keuangan pemerintah menjadi tepat waktu, akurat dan handal.

\section{Daftar Pustaka}

Abidin, K. M., Affifudin,\&Junaidi. (2018). Pengaruh Implementasi Sistem IManajemen Daerah (SIMDA), Kualitas Sumber Daya Manusia Dan Penerapan Standar Akuntansi Terhadap Kualitas Laporan Keuangan Pemerintah Daerah Kota Malang. E-JRA,.07(10). 130-141.

Ghozali, I. (2016). Aplikasi Analisis Multivariete Dengan Program IBM SPSS 23 (Edisi 8). Cetakan ke VIII. Semarang : Badan Penerbit Universitas Diponegoro. Hal 34.

Haq, A A. (2014). Kerangka Konseptual Akuntansi Pemerintah. Diakses tanggal 6 September 2019, dari : http://www.wikiapbn.org/kerangka-konseptual-akuntansi-pemerintahan/

Mahardini, N. Y \&Miranti, A.(2018).Dampak Penerapan Standar Akuntansi Pemerintah dan Kompetensi SDM Pada Kualitas Lporan Keuangan Pemerintah Provinsi Banten TA 2015. Jurnal Akuntansi, Vol 5 No. 1. Hal : 31.

Mahmudi, (2016).Analisis Laporan Keuangan Pemerintah Daerah, UPP Sekolah Tinggi Ilmu Manajemen YKPN, Yogyakarta. Hal : 13.

Nordiawan, D.\& Hertianti, A. (2010).Akuntansi Sektor Publik Edisi 2 Jakarta: Salemba Empat. Hal 21.

Pujanira, P. \& Taman, A. (2017).Pengaruh Kompetensi SDM, Penerapan Standar Akuntansi Pemerintah dan Penerapan Sistem Akuntansi Keuangan Daerah terhadap Kualitas Laporan Keuangan PemDa Provinsi DIY. Jurnal Nominal. Vol.VI No.2. Hal : 2634.

Ratmono, D, \& Sholihin, M. (2015).Akuntansi Keuangan Daerah Berbasis Akrual.Cetakan pertama. Upp STiE YKPN : Yogyakarta. 
Sako, U \& Lantowa F, D. (2018). Pengaruh Penerapan Standar Akuntansi Pemerintah Terhadap Kualitas Penyajian Laporan Keuangan Pada Pemerintah Kabupaten Gorontalo.Jurnal Of Accounting Science.Vol.2 No.1. Hal :43-53.

Sutaryo.(2011).Nilai Laporan Keuangan Pemerintah Dengan E-Government System (http://suteryofe.staff.uns.ac.id/2011/06/20/nilai-laporan-keuangan-pemerintahdengan-e-government-system/

Sekaran, U. (2014). Metodologi Penelitian untuk Bisnis (Research Methods for Business).Buku 1 Edisi 4. Salemba Empat. Jakarta.

Sudiarianti N. M., Ulupui I. Gusti.K. A \& Budiasih I. G.(2015). Pengaruh Kompetensi Sumber Daya Manusia Pada Penerapan Sistem Pengendalian Intern Pemerintah dan Standar Akuntansi Pemerintah Serta Implikasinya Pada Kualitas Laporan Keuangan Pemerintah Daerah.Prosiding.Simposium Nasional Akuntansi 18. Universitas Sumatera Utara, Medan. Hal : 5.

Wahyono, T. (2014).Sistem Informasi Akuntansi: Analisis, Desain dan Pemograman Komputer. Andi Offset:Yogyakarta.

www. https://bpkd.padangpanjang.go.id 